\title{
Sex-specific regulation of immune responses by PPARs
}

\author{
Hong-Jai Park ${ }^{1,2}$ and Je-Min Choi ${ }^{1,2}$
}

The prevalence of autoimmune, infectious and metabolic diseases is different for men and women owing to the respective ability of their immune systems to respond to self and foreign antigens. Although several factors, including hormones and the X-chromosome, have been suggested to contribute to such sex-specific immune responses, the underlying factors remain poorly defined. Recent studies using peroxisome proliferator-activated receptor (PPAR) ligands and knockout mice have identified sex-dimorphic expression of PPARs, and have shown that the inhibitory functions of PPAR in T cells are substantially affected by the sex hormones. In this review, we consider the sex-specific differences in PPARs and summarize the diverse PPAR-mediated, sex-specific properties of effector T-cell responses, such as T-cell activation, survival and differentiation, as well as their involvement in T-cell-related autoimmune diseases, including colitis, graft-versus-host disease and experimental autoimmune encephalomyelitis. Understanding PPAR-mediated sex differences in immune responses will provide more precise insights into the roles of PPARs in effector T cells.

Experimental \& Molecular Medicine (2017) 49, e364; doi:10.1038/emm.2017.102; published online 4 August 2017

\section{SEX DIFFERENCES IN THE INCIDENCE OF DISEASES}

Sex is a biological factor that contributes to physiological and anatomical differences. Immunological sex differences also exist and cause disparate responses to both self and foreign antigens. ${ }^{1}$ In general, males have a greater prevalence and severity of bacterial, fungal and parasitic infectious diseases than females. ${ }^{2}$ In addition, the RNA viral load in females with an acute HIV infection is $40 \%$ less than that in males, ${ }^{3}$ and the risk of death from malignant cancer is twofold higher in males than in females. ${ }^{1}$ Moreover, antibody production from vaccination against influenza virus is stronger in females than in males, demonstrating that females generate stronger immune responses than males. ${ }^{4}$ Although the heightened immune response of females is highly effective with respect to clearing pathogens and enhancing the vaccination efficiency, it also contributes to an increased susceptibility to inflammatory and autoimmune diseases compared with males. ${ }^{5,6}$ Indeed, there is a higher proportion of females with autoimmune disease than males, ${ }^{7-10}$ with females accounting for more than $60 \%$ of the incidence of Sjögren's syndrome, systemic lupus erythematosus (SLE), thyroid disease, rheumatoid arthritis, multiple sclerosis (MS) and Grave's disease. ${ }^{11-13}$

In addition to immune disease, there are also sex-specific differences in the prevalence of metabolic diseases. The risk of cardiovascular diseases is increased in females compared with that in males, whereas more males have type II diabetes mellitus. ${ }^{14,15}$ Insulin-sensitizing drugs also have sex-specific differences and are more effective in females as evidenced by reduced fasting plasma glucose levels. ${ }^{16}$ The genetic factors related to the sex chromosomes, ${ }^{17-19}$ microRNAs, ${ }^{20-22}$ hormonal mediators estrogen, ${ }^{23-26}$ progesterone, ${ }^{27-29}$ and androgens, ${ }^{30-33}$ and environmental mediators of nutrition ${ }^{34,35}$ and microbiota ${ }^{36-38}$ have all been suggested to affect sex-based differences in various diseases.

\section{SEX-SPECIFIC DIFFERENCES IN IMMUNE RESPONSES}

Innate immunity

Sex affects multiple aspects of innate immunity, which has an essential role in the regulation of non-specific and immediate defense against pathogens. ${ }^{39}$ Innate immune cells such as macrophages and dendritic cells (DCs) express several pattern-recognition receptors (PRRs) that recognize and respond to various antigens. Male peritoneal macrophages express higher levels of cell surface TLR4 protein than female cells, and lipopolysaccharide-challenged male mice have higher levels of pro-inflammatory cytokine and chemokine production, including IL-6, IL- $1 \beta$ and IL- $10 .{ }^{40,41}$ Male neutrophils also show higher expression of TLR 4 and produce greater amounts of TNF- $\alpha$ than female cells following lipopolysaccharide stimulation. ${ }^{42}$ These inflammatory responses in males are

\footnotetext{
${ }^{1}$ Department of Life Science, College of Natural Sciences, Hanyang University, Seoul, Republic of Korea and ${ }^{2}$ Research Institute for Natural Sciences, Hanyang University, Seoul, Republic of Korea

Correspondence: Professor J-M Choi, Department of Life Science, College of Natural Sciences, Hanyang University, 222 Wangsimni-ro, Seongdong-gu, Seoul 04763, Republic of Korea.

E-mail: jeminchoi@hanyang.ac.kr

Received 16 December 2016; revised 15 February 2017; accepted 5 March 2017
} 
believed to be responsible for the greater susceptibility of males to bacterial septic shock. In addition, viral ligand-induced TLR9 activation of male peripheral blood mononuclear cells (PBMCs) results in a greater production of IL-10 than that of female cells, a finding that is highly correlated with the plasma level of sex hormones as IL-10 cytokine production between males and post-menopausal women does not show any differences compared with males and females at reproductive age. ${ }^{43}$

The promoter regions of genes in innate immune cells contain putative androgen, glucocorticoid and estrogen elements $^{44}$ suggesting that hormones have profound effects on the function of innate immunity. Compared to males, females have greater TLR7 gene expression. As TLR7 is encoded on the $\mathrm{X}$-chromosome, the increased expression in females may be due to incomplete $\mathrm{X}$ inactivation, whereas males have a potentially lower expression level of TLR7. ${ }^{45-47}$ Female PBMCs and plasmacytoid DCs (pDCs) also have increased IFN- $\alpha$ production compared to male cells following TLR7 ligand stimulation, ${ }^{48,49}$ which is associated with reduced viral RNA following viral infection. ${ }^{44}$ Interestingly, castrated male mice have anti-viral responses that are comparable with those of females, including the induction of PRRs and anti-viral genes, ${ }^{19}$ providing further evidence of the role of sex in the innate immune response.

\section{Adaptive immunity}

Sex influences the adaptive immune system, and several studies have shown that females generate a stronger immune response than males. For example, the proportion of $\mathrm{CD} 4^{+} \mathrm{T}$ cells and Treg cells within the total $\mathrm{CD} 4^{+}$population is higher in females than in males, whereas males have a higher number of $\mathrm{CD} 8^{+}$ T cells. ${ }^{50-53}$ Owing to the higher number of $\mathrm{CD}^{+} \mathrm{T}$ cells, females generate a higher number of activated $\mathrm{CD}^{+} \mathrm{T}$ cells than males following T-cell receptor (TCR) stimulation. ${ }^{54}$ Interestingly, anti-viral and pro-inflammatory genes are upregulated to a greater degree in activated female cytotoxic $\mathrm{T}$ cells than in male cells, and half of these genes have estrogenresponse elements (EREs) in their promoter region, ${ }^{55}$ suggesting that sex hormones may influence the regulation of cytotoxic T-cell activity.

Females have robust Th1 responses, and female $\mathrm{CD} 4^{+} \mathrm{T}$ cells produce higher levels of IFN- $\gamma$ than male T cells. IFN- $\gamma$ serves as an important factor in the onset of experimental autoimmune encephalomyelitis (EAE). ${ }^{56}$ The enhanced production of IFN- $\gamma$ by CD4 ${ }^{+} \mathrm{T}$ cells in females is responsible for their superior protection against infectious diseases such as Leishmania. $^{2}$ In addition, female $\mathrm{CD}^{+} \mathrm{T}$ cells produce less IL-17 than male $\mathrm{CD}^{+}{ }^{+} \mathrm{T}$ cells, ${ }^{33}$ further demonstrating sex-specific differences in $\mathrm{CD}^{+}{ }^{+} \mathrm{T}$-cell-mediated cytokine production in males and females. Females also display greater antibody responses, including higher B-cell numbers and basal immunoglobulin levels, than males, ${ }^{57,58}$ possibly leading to faster viral clearance in females. Finally, antibody responses to viral and bacterial vaccines are higher in females than in males, suggesting that vaccination efficacy is better in females than in males. For example, a half dose of vaccination against influenza virus in females results in similar antibody production to that of a full dose of vaccine in males. ${ }^{59}$

\section{THE ROLE OF PEROXISOME PROLIFERATOR-ACTIVATED RECEPTORS IN THE IMMUNE RESPONSE}

Peroxisome proliferator-activated receptors (PPARs) are nuclear receptors that regulate lipid and glucose metabolism, ${ }^{60-63}$ as well as cell survival ${ }^{64}$ and immunity. ${ }^{65-67}$ Tissues that require high amounts of energy to maintain their own function, such as liver, adipose, muscle and heart tissues, have high expression of PPARs, ${ }^{68}$ implying that PPARs act as regulators of metabolism. PPARs are also expressed in various immune cells such as monocytes, macrophages, $\mathrm{T}$ cells and $\mathrm{B}$ cells, ${ }^{69,70}$ where they may also regulate immune function.

PPAR $\alpha$ is expressed in macrophages, granulocytes and lymphocytes. ${ }^{70}$ Ligand-activated PPAR $\alpha$ represses NF-кB activity and IL-2 production in lymphocytes, ${ }^{70}$ and regulates IL-4- and IL-5-induced expression of target genes in T cells. ${ }^{71}$ PPAR $\alpha$-deficient T cells produce higher amounts of IFN- $\gamma$ and TNF- $\alpha$ with increased NF- $\kappa \mathrm{B}$ and $\mathrm{c}$-jun activity compared to wild-type $\mathrm{T}$ cells. PPAR $\alpha$-deficient mice are also susceptible to EAE, indicating that $\operatorname{PPAR} \alpha$ has an anti-inflammatory function as a negative regulator of T cells. ${ }^{56}$ The PPAR $\alpha$ ligand fenofibrate effectively reduces the severity of both EAE and colitis by inhibiting IFN- $\gamma$ and IL-17 production, ${ }^{71-73}$ indicating that PPAR $\alpha$ ligands may be useful for the treatment of autoimmune diseases. In addition, PPAR $\alpha$ has an important role in the suppression of allergic contact dermatitis by Treg cells ${ }^{74}$ as the proportion and suppressive function of Treg cells are decreased in PPAR $\alpha$-deficient mice.

The PPAR $\beta / \delta$ agonist GW-0742 has protective, immunemodulatory functions against EAE. ${ }^{75}$ On the other hand, mice lacking PPAR $\beta / \delta$ expression display severe EAE clinical signs with significant accumulation of IFN- $\gamma^{+} \mathrm{IL}-17 \mathrm{~A}^{-}$ and IFN- $\gamma^{+}$IL-17A ${ }^{+} \mathrm{T}$ cells in the spinal cord. ${ }^{76}$ Additional anti-inflammatory functions of PPAR $\beta / \delta$ have been identified, including the fact that they are essential for the clearance of apoptotic cells. ${ }^{77}$ Specifically, treatment with PPAR $\beta / \delta$ ligands augments the clearance of apoptotic cells, whereas delayed uptake of the cells found in the absence of $\operatorname{PPAR} \beta / \delta$ results in a SLE-like autoimmune disease. These findings suggest that $\operatorname{PPAR} \beta / \delta$ also has a significant role in inhibiting $\mathrm{T}$-cell activation and preventing autoimmune disease.

PPAR $\gamma$ has two isoforms, with PPAR $\gamma 1$ distributed in most tissues and PPAR $\gamma 2$ dominantly expressed in adipose tissue. ${ }^{68,78}$ PPAR $\gamma$ ligands have inhibitory effects on monocyte TNF- $\alpha, \quad$ IL- $1 \beta$ and IL- 6 cytokine production. ${ }^{79,80}$ PPAR $\gamma$ ligands and knockout mouse studies have demonstrated the importance of PPAR $\gamma$ in T-cell activation, survival, differentiation and autoimmune disease. The PPAR $\gamma$ ligands $15 \mathrm{~d}-\mathrm{PGJ}_{2}$ and ciglitazone inhibit IL-2 cytokine production and proliferation of $\mathrm{T}$ cells, ${ }^{81}$ demonstrating the importance of functional PPAR $\gamma$ expression for the ligand-mediated regulation of immune responses. PPAR $\gamma$ expression is decreased in the 

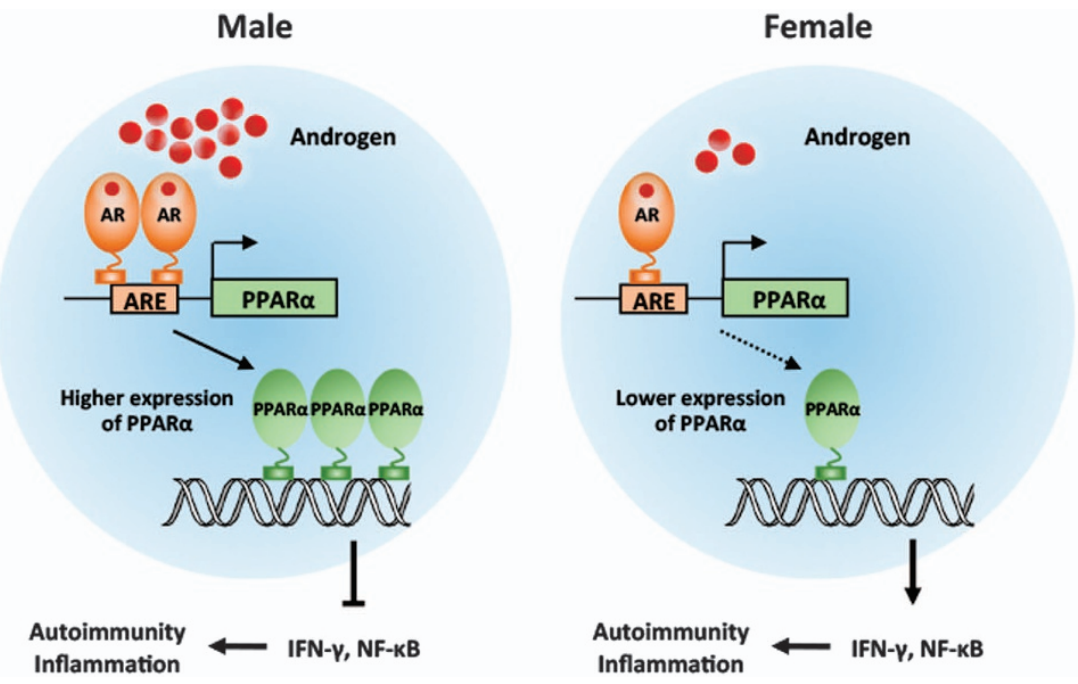

Figure 1 An androgen-sufficient environment enhances PPAR $\alpha$ activity to regulate autoimmunity by suppressing IFN- $\gamma$ production. Males have higher androgen hormone levels than females, and this androgen-sufficient environment contributes to enhanced PPAR $\alpha$ expression in male $T$ cells by bringing the androgen receptor (AR) to the ARE present in the promoter region of the PPAR $\alpha$ gene. Increased expression of PPAR $\alpha$ by androgen hormone inhibits NF- $\mathrm{KB}$ activity and IFN- $\gamma$ production in male $\mathrm{T}$ cells following TCR stimulation to control inflammation and autoimmunity, such as in experimental autoimmune encephalomyelitis (EAE). In contrast to males, limited amounts of androgen hormone in females do not lead to increased expression of PPAR $\alpha$, which, in turn, fails to suppress NF-кB activity and IFN- $\gamma$ production in female T cells.

PBMCs of MS patients compared with that in healthy controls, 82 and pioglitazone treatment suppresses the human allogenic T-cell response in an arterial graft model, ${ }^{83}$ altogether indicating that PPAR $\gamma$ expression and activation have an important role in preventing the onset of autoimmune disease and graft rejection.

PPAR $\gamma$ has been reported to be indispensable for the accumulation of Treg cells in visceral adipose tissue (VAT). Treg cells do not accumulate in the VAT of mice with Foxp3-specifically deleted of PPAR $\gamma,{ }^{84}$ indicating that PPAR $\gamma$ is a crucial mediator of Treg cell accumulation, phenotype and function by regulating the expression of chemokine receptors necessary for the migration of Treg cells. Recent studies have also revealed an important role for PPAR $\gamma$ in the loss of the VAT Treg cell phenotype resulting from the phosphorylation of the serine residue at the PPAR $\gamma$ position $273 .{ }^{85}$ Specifically, this PPAR $\gamma$ serine residue acts as a checkpoint for whether VAT Tregs will retain their characteristic transcriptional signature.

PPAR $\gamma$ expression in regulatory $\mathrm{T}$ (Treg) cells has an essential role in preventing colitis ${ }^{86}$ and graft-versus-host disease (GVHD) ${ }^{87}$ PPAR $\gamma$-deficient Treg cells have an impaired ability to downregulate effector T-cell-mediated colitis and GVHD, suggesting that the expression of PPAR $\gamma$ in Treg cells is essential for the inhibitory function of these cells in the immune response, and points to the immune-therapeutic potential of targeting PPAR $\gamma$. However, this finding is contradicted by a report that PPAR $\gamma$ is required for the development of autoimmune diseases such as colitis under lymphopenic conditions due to the apoptotic characteristics of PPAR $\gamma$-deficient T cells with decreased levels of IL-7R $\alpha .{ }^{88}$

\section{SEX-SPECIFIC PPAR $\alpha$-DEPENDENT DIFFERENCES IN IMMUNE RESPONSES}

PPAR $\alpha$ expression is more abundant in naïve and activated male $\mathrm{T}$ cells than in female cells, ${ }^{56}$ suggesting that PPAR $\alpha$ has a more substantial role in male $\mathrm{T}$ cells than in female $\mathrm{T}$ cells. The production of IFN- $\gamma$ and TNF- $\alpha$, but not that of IL-17, is significantly increased in PPAR $\alpha$-deleted male $\mathrm{T}$ cells with augmented NF- $\mathrm{BB}$ and c-jun activity, ${ }^{56}$ implying that PPAR $\alpha$ effectively inhibits the production of inflammatory cytokines in males. Moreover, male PPAR $\alpha$-deficient mice are more susceptible to developing EAE with increased level of cytokines, including IFN- $\gamma$, TNF- $\alpha$ and IL-2, whereas female PPAR $\alpha-$ deficient mice have comparable cytokine production and EAE pathogenesis compared to sex-matched littermate controls. ${ }^{56}$ These findings suggest that PPAR $\alpha$ can control the immune responses in males due to its increased expression. ${ }^{56}$

The male hormone androgen has been suggested to influence the expression of PPAR $\alpha$ in male T cells. Chip analysis has shown that the androgen receptor can interact with the promoter region of PPAR $\alpha .{ }^{33}$ Furthermore, castrated male mice exhibit increased Th1-cell infiltration into the CNS compared with the weak Th1 infiltration seen in sham male mice, as well as increased IFN- $\gamma$ and decreased IL-17 cytokine production. Altogether, these data suggest that the androgen hormone is essential for maintaining PPAR $\alpha$ expression in males to inhibit Th1 responses in the mouse EAE model. ${ }^{33,89}$ In human $\mathrm{T}$ cells, PPAR $\alpha$-mediated suppression of IFN- $\gamma$ production is more sensitive in males than in females. ${ }^{33}$ Treatment of male $\mathrm{T}$ cells with PPAR $\alpha$ siRNA results in increased IFN- $\gamma$ production, whereas PPAR $\gamma$ siRNAtransfected female T cells have augmented IL-17 expression, suggesting that the different regulatory roles of PPAR $\alpha$ and 
Female

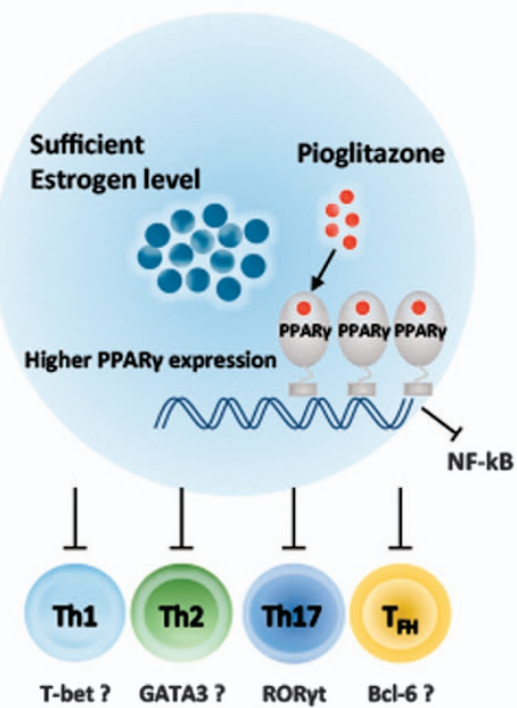

Male

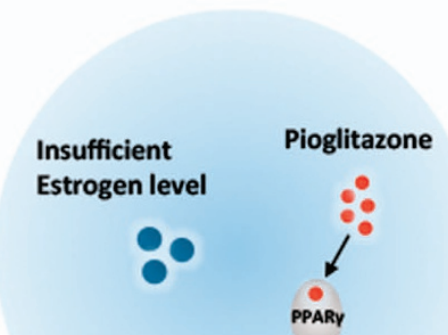

Lower PPARy expression
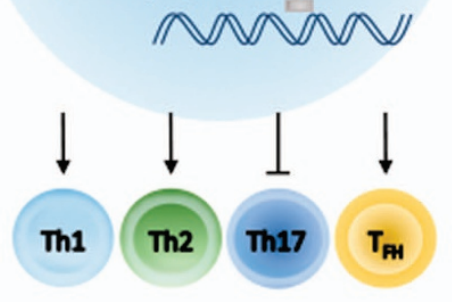

Male + Estradiol

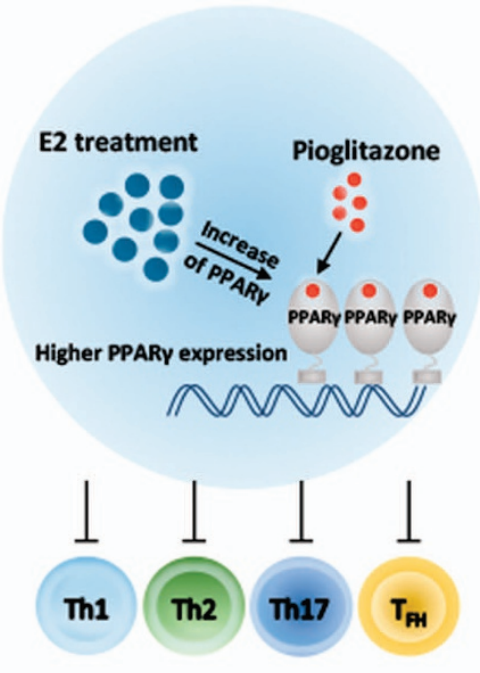

Figure 2 An estrogen-sufficient environment promotes PPAR $\gamma$ activity to regulate effector T-cell responses. The estrogen-sufficient environment in females contributes to increased PPAR $\gamma$ expression levels in female T cells. A higher expression level of PPAR $\gamma$ enables female $T$ cells to respond more effectively than male T cells to treatment with the PPAR $\gamma$ ligand pioglitazone to regulate Th1, Th2, Th17 and $T_{F H}$ cells. In contrast, males have lower expression of PPAR $\gamma$ due to limited available estrogen hormone. Thus, they fail to suppress Th1, Th2 and $\mathrm{T}_{\mathrm{FH}}$ cells in the presence of the PPAR $\gamma$ ligand pioglitazone, but instead exhibit the selective inhibition of Th17-cell differentiation. Estradiol administration in males enhances PPAR $\gamma$ expression and rescues pioglitazone-mediated repression of Th1, Th2 and $\mathrm{T}_{\mathrm{FH}}$ cells as seen in females. Thus, sufficient levels of estrogen are advantageous for promoting PPAR $\gamma$ activity, and a synergistic effect between pioglitazone and estrogen is critical for effector T-cell responses.

PPAR $\gamma$ are dependent on sex. The sex-specific role of PPAR $\alpha$ in $\mathrm{T}$ cells is summarized in Figure 1.

\section{SEX-SPECIFIC PPAR $\gamma$-DEPENDENT DIFFERENCES IN IMMUNE RESPONSES}

The basal expression of PPAR $\gamma$ in $\mathrm{CD}^{+} \mathrm{T}$ cells is higher than that in $\mathrm{CD}^{+} \mathrm{T}$ cells and $\mathrm{B}$ cells. ${ }^{90}$ The expression of PPAR $\gamma$ is also increased in $\mathrm{CD}^{+} \mathrm{T}$ cells following TCR stimulation. ${ }^{56,90}$ PPAR $\gamma$ expression is also higher in female $\mathrm{T}$ cells than in males, ${ }^{33,56,91}$ and the treatment of male $\mathrm{T}$ cells with estradiol enhances the expression of PPAR $\gamma$, suggesting that the female sex hormone estrogen profoundly influences the expression of PPAR $\gamma$ in T cells. These data may also suggest that PPAR $\gamma$ may be more sensitively regulated by PPAR $\gamma$ ligand treatment in female $\mathrm{T}$ cells than in male $\mathrm{T}$ cells. In addition, PPAR $\gamma$ expression is higher in the estrus phase of the menstrual cycle than in the diestrus phase, ${ }^{91}$ further demonstrating the importance of sex hormones in the regulation of PPAR $\gamma$ in females.

Recently, a study on the sex-specific differences regarding the role of PPAR $\gamma$ in T-cell survival showed that male PPAR $\gamma$-deficient $\mathrm{T}$ cells undergo increased apoptosis with decreased levels of $\mathrm{Bcl}-2$ and IL-7R $\alpha$, and comprise a larger proportion of apoptotic cells than female PPAR $\gamma$-deficient T cells. ${ }^{91}$ Another report suggested that PPAR $\gamma$ is required for the development of colitis in lymphopenic conditions, and that a lack of PPAR $\gamma$ results in decreased IL-7R $\alpha$, suggesting an important role of PPAR $\gamma$ in T-cell survival. ${ }^{88}$ Although more convincing data are required to solve this discrepancy, PPAR $\gamma$ may function as a survival factor in female $\mathrm{T}$ cells.

PPAR $\gamma$ ligand studies have shown that PPAR $\gamma$ acts as a negative regulator of T-cell activation by inhibiting NF- $\kappa B$ and NFAT transcription factors ${ }^{92}$ to suppress cytokine production and proliferation. PPAR $\gamma$-deficient T cells also have increased levels of cytokines and NF- $\kappa$ B activity following TCR stimulation..$^{90}$ This inhibitory role of PPAR $\gamma$ in T-cell activation is observed in female PPAR $\gamma$-deficient $\mathrm{T}$ cells, but not in male $\mathrm{T}$ cells, suggesting that PPAR $\gamma$ is more important in females for NF- $\mathrm{B}$ regulation. In addition, female PPAR $\gamma$-deficient $\mathrm{T}$ cells produce enhanced lineage-specific cytokines in Th1, Th2, Th17 and Th9 cells under T-cell-differentiation-skewing conditions. ${ }^{90}$ Recently, the sex-specific regulatory functions of PPAR $\gamma$ have been investigated in the differentiation of Th1, Th2 and Th17 cells between males and females. The PPAR $\gamma$ ligand pioglitazone inhibits the differentiation of female Th1, Th2 and Th17 cells, whereas it specifically reduces only Th17-cell differentiation in males. ${ }^{93}$ These findings suggest that PPAR $\gamma$ profoundly and non-specifically influences the differentiation of female $\mathrm{T}$ cells but selectively inhibits the formation of male Th17 cells. Although pioglitazone single treatment does not affect the differentiation of Th1 and Th2 cells in male $\mathrm{T}$ cells, estradiol enhances PPAR $\gamma$ expression and suppresses Th1 and Th2-cell differentiation, ${ }^{93}$ suggesting that PPAR $\gamma$ may have stronger effects on inflammatory and allergic diseases in an estrogen-repleted environment. These data are supported by 
another recent study that investigated the sex-specific regulatory functions of PPAR $\gamma$, showing that PPAR $\gamma$ selectively inhibits the differentiation of Th17 cells, but not that of Th1, Th2 and Treg cells, by suppressing the ROR $\gamma \mathrm{t}$ transcription factor without affecting T-bet, GATA3 or Foxp3. ${ }^{94}$

The sex-specific functional activity of PPAR $\gamma$ has been proposed for $\mathrm{T}_{\mathrm{FH}}$ cells and germinal center (GC) responses. ${ }^{90}$ Spontaneous autoantibody production, glomerular inflammation and increased $\mathrm{T}_{\mathrm{FH}}$ cells identified as $\mathrm{CD} 4^{+} \mathrm{CD} 44^{\text {high }}$ PSGL1 $1^{\text {low }}$ CXCR $^{+}$PD- $1^{+}, 95$ and GC reactions are present in female CD4-PPAR $\gamma^{\mathrm{KO}}$ mice, but not in male mice, suggesting that PPAR $\gamma$ regulates $\mathrm{T}_{\mathrm{FH}}$ responses more sensitively in females than in males. $\mathrm{T}_{\mathrm{FH}}$ responses are suppressed by PPAR $\gamma$ in SRBC- or NP-OVA-immunized mouse models. ${ }^{90,91}$ Interestingly, this regulatory function of PPAR $\gamma$ in $\mathrm{T}_{\mathrm{FH}}$ responses and autoimmune phenotypes is sex-specific. ${ }^{91}$ Specifically, the $\operatorname{PPAR} \gamma$ ligand pioglitazone reduces $\mathrm{CD} 4^{+} \mathrm{CD} 44^{\text {high }} \mathrm{Bcl}-6^{+}$ CXCR5 $^{+} \mathrm{T}_{\mathrm{FH}}$ cells and GC formation only in females dependent on estrogen, and this response is well-correlated with PPAR $\gamma$ expression..$^{91}$ Estradiol administration in males increases the expression of PPAR $\gamma$, and pioglitazone also inhibits $\mathrm{T}_{\mathrm{FH}}$-cell and $\mathrm{GC}$ responses in males. This result implies that estrogen sufficiency is advantageous for promoting PPAR $\gamma$ activity, and that the synergistic effect of pioglitazone and estrogen is critical for controlling $\mathrm{T}_{\mathrm{FH}}$ responses. The sex-specific regulatory roles of PPAR $\gamma$ in effector $\mathrm{T}$ cells are summarized in Figure 2.

\section{SEX-SPECIFIC PPAR $\beta / \delta$-DEPENDENT DIFFERENCES IN IMMUNE RESPONSES}

The role of PPAR $\beta / \delta$ was investigated in the EAE animal model, and PPAR $\beta / \delta$ was shown to suppress the production of IFN- $\gamma$, IL-17, IL-12p35 and IL-12p40 in the brain and spleen, and ameliorate EAE independent of sex. ${ }^{96}$ This result may be due to the comparable level of PPAR $\beta / \delta$ expression in male and female naive and activated T cells. ${ }^{56}$ On the other hand, female skeletal muscle has higher PPAR $\beta / \delta$ mRNA expression than males but comparable levels of protein. ${ }^{97}$ Although the regulatory role of $P P A R \beta / \delta$ in $\mathrm{T}$ cells has not been well studied, sex-specific differences in the regulation of PPAR $\beta / \delta$ should be considered in future studies.

\section{CONCLUSIONS}

In general, the prevalence of autoimmune, infectious and metabolic diseases are distinctly different for males and females. Sex-specific differences in immune responses contribute to the differences in both the prevalence and severity of these diseases. More specifically, the recent literature has suggested that the sex-specific functional regulation of PPARs in $\mathrm{T}$ cells is mediated by sex hormones, including estrogen and androgen, which may provide an explanation for the observed differences in disease outcomes. Therapeutic strategies using PPAR ligands in T-cell-mediated diseases such as autoimmune disease should consider co-treatment with sex hormones. Further studies will be required to more precisely elucidate the molecular mechanisms of PPARs and other transcription factors that regulate effector T-cell functions and hormonal responses.

\section{CONFLICT OF INTEREST}

The authors declare no conflict of interest.

\section{ACKNOWLEDGEMENTS}

This work was supported by grants from the Korea Health Technology R\&D project through the Korea Health Industry Development Institute (KHIDI) funded by the Ministry of Health \& Welfare, Republic of Korea (HI14C0234) and the research fund of Hanyang University (HY-2013-00000001472) to J-MC.

1 Klein SL, Flanagan KL. Sex differences in immune responses. Nat Rev Immunol 2016; 16: 626-638.

2 Roberts CW, Walker W, Alexander J. Sex-associated hormones and immunity to protozoan parasites. Clin Microbiol Rev 2001; 14: 476-488.

3 Ziegler S, Altfeld M. Sex differences in HIV-1-mediated immunopathology. Curr Opin HIV AIDS 2016; 11: 209-215.

4 Klein SL, Jedlicka A, Pekosz A. The Xs and $Y$ of immune responses to viral vaccines. Lancet Infect Dis 2010; 10: 338-349.

5 Whitacre CC. Sex differences in autoimmune disease. Nat Immunol 2001; 2: 777-780.

6 Oertelt-Prigione S. The influence of sex and gender on the immune response. Autoimmun Rev 2012; 11: A479-A485.

7 Jacobson DL, Gange SJ, Rose NR, Graham NM. Epidemiology and estimated population burden of selected autoimmune diseases in the United States. Clin Immunol Immunopathol 1997; 84: 223-243.

8 Fairweather D, Frisancho-Kiss S, Rose NR. Sex differences in autoimmune disease from a pathological perspective. Am J Pathol 2008; 173: 600-609.

9 Fairweather D, Rose NR. Women and autoimmune diseases. Emerg Infect Dis 2004; 10: 2005-2011.

10 Voskuhl R. Sex differences in autoimmune diseases. Biol Sex Differ 2011; 2: 1.

11 Ciháková D, Talor MV, Barin JG, Baldeviano GC, Fairweather D, Rose NR et al. Sex differences in a murine model of Sjögren's syndrome. Ann NY Acad Sci 2009; 1173: 378-383.

12 Golden LC, Voskuhl R. The importance of studying sex differences in disease: The example of multiple sclerosis. J Neurosci Res 2017; 95: 633-643.

13 Papenfuss TL, Rogers CJ, Gienapp I, Yurrita M, McClain M, Damico N et al. Sex differences in experimental autoimmune encephalomyelitis in multiple murine strains. J Neuroimmunol 2004; 150: 59-69.

14 Yki-Järvinen H. Sex and insulin sensitivity. Metabolism 1984; 33: $1011-1015$

15 Nuutila P, Knuuti MJ, Mäki M, Laine H, Ruotsalainen U, Teräs M et al. Gender and insulin sensitivity in the heart and in skeletal muscles. Studies using positron emission tomography. Diabetes 1995; 44: 31-36.

16 Patel J, Anderson RJ, Rappaport EB. Rosiglitazone monotherapy improves glycaemic control in patients with type 2 diabetes: a twelve-week, randomized, placebo-controlled study. Diabetes Obes Metab 1999; 1: 165-172.

17 Libert C, Dejager L, Pinheiro I. The X chromosome in immune functions: when a chromosome makes the difference. Nat Rev Immunol 2010; 10: 594-604.

18 Smith-Bouvier DL, Divekar AA, Sasidhar M, Du S, Tiwari-Woodruff SK, King JK et al. A role for sex chromosome complement in the female bias in autoimmune disease. J Exp Med 2008; 205: 1099-1108.

19 Robinson DP, Huber SA, Moussawi M, Roberts B, Teuscher C, Watkins R et al. Sex chromosome complement contributes to sex differences in coxsackievirus B3 but not influenza A virus pathogenesis. Biol Sex Differ 2011; $2: 8$.

20 Sharma S, Eghbali M. Influence of sex differences on microRNA gene regulation in disease. Biol Sex Differ 2014; 5: 3.

21 Pinheiro I, Dejager L, Libert C. X-chromosome-located microRNAs in immunity: might they explain male/female differences? The $X$ chromosome-genomic context may affect $\mathrm{X}$-located miRNAs and 
downstream signaling, thereby contributing to the enhanced immune response of females. Bioessays 2011; 33: 791-802.

22 Dai R, McReynolds S, Leroith T, Heid B, Liang Z, Ahmed SA. Sex differences in the expression of lupus-associated miRNAs in splenocytes from lupus-prone NZB/WF1 mice. Biol Sex Differ 2013; 4: 19.

23 Phiel KL, Henderson RA, Adelman SJ, Elloso MM. Differential estrogen receptor gene expression in human peripheral blood mononuclear cell populations. Immunol Lett 2005; 97: 107-113.

24 Kovats S. Estrogen receptors regulate innate immune cells and signaling pathways. Cell Immunol 2015; 294: 63-69.

25 Bouman A, Heineman MJ, Faas MM. Sex hormones and the immune response in humans. Hum Reprod Update 2005; 11: 411-423.

26 Straub RH. The complex role of estrogens in inflammation. Endocr Rev 2007; 28: 521-574.

27 Butts CL, Shukair SA, Duncan KM, Bowers E, Horn C, Belyavskaya E et al. Progesterone inhibits mature rat dendritic cells in a receptor-mediated fashion. Int Immunol 2007; 19: 287-296.

28 Jones LA, Kreem S, Shweash M, Paul A, Alexander J, Roberts CW. Differential modulation of TLR3- and TLR4-mediated dendritic cell maturation and function by progesterone. J Immunol 2010; 185: 4525-4534.

29 Menzies FM, Henriquez FL, Alexander J, Roberts CW. Selective inhibition and augmentation of alternative macrophage activation by progesterone. Immunology 2011; 134: 281-291.

30 Liva SM, Voskuhl RR. Testosterone acts directly on CD4+ T lymphocytes to increase IL-10 production. J Immunol 2001; 167: 2060-2067.

31 Malkin CJ, Pugh PJ, Jones RD, Kapoor D, Channer KS, Jones TH. The effect of testosterone replacement on endogenous inflammatory cytokines and lipid profiles in hypogonadal men. J Clin Endocrinol Metab 2004; 89: 3313-3318.

32 Bobjer J, Katrinaki M, Tsatsanis C, Lundberg Giwercman Y, Giwercman A. Negative association between testosterone concentration and inflammatory markers in young men: a nested cross-sectional study. PLOS ONE 2013; 8: e61466.

33 Zhang MA, Rego D, Moshkova M, Kebir H, Chruscinski A, Nguyen $\mathrm{H}$ et al. Peroxisome proliferator-activated receptor (PPAR)alpha and -gamma regulate IFNgamma and IL-17A production by human T cells in a sex-specific way. Proc Natl Acad Sci USA 2012; 109: 9505-9510.

34 Sinha A, Madden J, Ross-Degnan D, Soumerai S, Platt R. Reduced risk of neonatal respiratory infections among breastfed girls but not boys. Pediatrics 2003; 112: e303.

35 Kawai K, Msamanga G, Manji K, Villamor E, Bosch RJ, Hertzmark E et al. Sex differences in the effects of maternal vitamin supplements on mortality and morbidity among children born to HIV-infected women in Tanzania. Br J Nutr 2010; 103: 1784-1791.

36 Markle JG, Frank DN, Mortin-Toth S, Robertson CE, Feazel LM, Rolle-Kampczyk $U$ et al. Sex differences in the gut microbiome drive hormone-dependent regulation of autoimmunity. Science 2013; 339: 1084-1088.

37 Yurkovetskiy L, Burrows M, Khan AA, Graham L, Volchkov P, Becker L et al. Gender bias in autoimmunity is influenced by microbiota. Immunity 2013; 39: 400-412.

38 Bolnick DI, Snowberg LK, Hirsch PE, Lauber CL, Org E, Parks B et al. Individual diet has sex-dependent effects on vertebrate gut microbiota. Nat Commun 2014; 5: 4500.

39 Moxley G, Posthuma D, Carlson P, Estrada E, Han J, Benson LL et al. Sexual dimorphism in innate immunity. Arthritis Rheum 2002; 46: 250-258.

40 Marriott I, Bost KL, Huet-Hudson YM. Sexual dimorphism in expression of receptors for bacterial lipopolysaccharides in murine macrophages: a possible mechanism for gender-based differences in endotoxic shock susceptibility. J Reprod Immunol 2006; 71: 12-27.

41 Rettew JA, Huet-Hudson YM, Marriott I. Testosterone reduces macrophage expression in the mouse of toll-like receptor 4 , a trigger for inflammation and innate immunity. Biol Reprod 2008; 78: 432-437.

42 Aomatsu M, Kato T, Kasahara E, Kitagawa S. Gender difference in tumor necrosis factor- $\alpha$ production in human neutrophils stimulated by lipopolysaccharide and interferon- $\gamma$. Biochem Biophys Res Commun 2013; 441: 220-225.

43 Torcia MG, Nencioni L, Clemente AM, Civitelli L, Celestino I, Limongi D et al. Sex differences in the response to viral infections: TLR8 and TLR9 ligand stimulation induce higher IL10 production in males. PLOS ONE 2012: 7: e39853.
44 Hannah MF, Bajic VB, Klein SL. Sex differences in the recognition of and innate antiviral responses to Seoul virus in Norway rats. Brain Behav Immun 2008; 22: 503-516.

45 Pisitkun P, Deane JA, Difilippantonio MJ, Tarasenko T, Satterthwaite AB, Bolland S. Autoreactive B cell responses to RNA-related antigens due to TLR7 gene duplication. Science 2006; 312: 1669-1672.

46 Laffont S, Rouquié N, Azar P, Seillet C, Plumas J, Aspord C et al. $\mathrm{X}$-chromosome complement and estrogen receptor signaling independently contribute to the enhanced TLR7-mediated IFN- $\alpha$ production of plasmacytoid dendritic cells from women. J Immunol 2014; 193: 5444-5452.

47 Chen X, McClusky R, Chen J, Beaven SW, Tontonoz P, Arnold AP et al. The number of $\mathrm{X}$ chromosomes causes sex differences in adiposity in mice. PLoS Genet 2012; 8: e1002709.

48 Berghöfer B, Frommer T, Haley G, Fink L, Bein G, Hackstein H. TLR7 ligands induce higher IFN-alpha production in females. J Immunol 2006; 177: 2088-2096.

49 Griesbeck M, Ziegler S, Laffont S, Smith N, Chauveau L, Tomezsko P et al. Sex differences in plasmacytoid dendritic cell levels of IRF5 drive higher IFN- $\alpha$ production in women. J Immunol 2015; 195: 5327-5336.

50 Abdullah M, Chai PS, Chong MY, Tohit ER, Ramasamy R, Pei CP et al. Gender effect on in vitro lymphocyte subset levels of healthy individuals. Cell Immunol 2012; 272: 214-219.

51 Lee BW, Yap HK, Chew FT, Quah TC, Prabhakaran K, Chan GS et al. Age- and sex-related changes in lymphocyte subpopulations of healthy Asian subjects: from birth to adulthood. Cytometry 1996; 26: 8-15.

52 Uppal SS, Verma S, Dhot PS. Normal values of CD4 and CD8 lymphocyte subsets in healthy Indian adults and the effects of sex, age, ethnicity, and smoking. Cytometry B Clin Cytom 2003; 52: 32-36.

53 Lisse IM, Aaby P, Whittle H, Jensen H, Engelmann M, Christensen LB. T-lymphocyte subsets in West African children: impact of age, sex, and season. J Pediatr 1997; 130: 77-85.

54 Sankaran-Walters S, Macal M, Grishina I, Nagy L, Goulart L, Coolidge K et al. Sex differences matter in the gut: effect on mucosal immune activation and inflammation. Biol Sex Differ 2013; 4: 10.

55 Hewagama A, Patel D, Yarlagadda S, Strickland FM, Richardson BC. Stronger inflammatory/cytotoxic T-cell response in women identified by microarray analysis. Genes Immun 2009; 10: 509-516.

56 Dunn SE, Ousman SS, Sobel RA, Zuniga L, Baranzini SE, Youssef S et al. Peroxisome proliferator-activated receptor (PPAR)alpha expression in $T$ cells mediates gender differences in development of $T$ cell-mediated autoimmunity. J Exp Med 2007; 204: 321-330.

57 Furman D, Hejblum BP, Simon N, Jojic V, Dekker CL, Thiébaut R et al. Systems analysis of sex differences reveals an immunosuppressive role for testosterone in the response to influenza vaccination. Proc Natl Acad Sci USA 2014; 111: 869-874.

58 Furman D. Sexual dimorphism in immunity: improving our understanding of vaccine immune responses in men. Expert Rev Vaccines 2015; 14: 461-471.

59 Engler RJ, Nelson MR, Klote MM, VanRaden MJ, Huang CY, Cox NJ et al. Half- vs full-dose trivalent inactivated influenza vaccine (2004-2005): age, dose, and sex effects on immune responses. Arch Intern Med 2008; 168: 2405-2414.

60 Tontonoz P, Hu E, Spiegelman BM. Stimulation of adipogenesis in fibroblasts by PPAR gamma 2, a lipid-activated transcription factor. Cell 1994; 79: 1147-1156.

61 Forman BM, Tontonoz P, Chen J, Brun RP, Spiegelman BM, Evans RM. 15-Deoxy-delta 12, 14-prostaglandin $\mathrm{J} 2$ is a ligand for the adipocyte determination factor PPAR gamma. Cell 1995; 83: 803-812.

62 Kliewer SA, Lenhard JM, Willson TM, Patel I, Morris DC, Lehmann JM. A prostaglandin J2 metabolite binds peroxisome proliferator-activated receptor gamma and promotes adipocyte differentiation. Cell 1995; 83: 813-819.

63 Hamm JK, el Jack AK, Pilch PF, Farmer SR. Role of PPAR gamma in regulating adipocyte differentiation and insulin-responsive glucose uptake. Ann N Y Acad Sci 1999; 892: 134-145.

64 Jo SH, Yang C, Miao Q, Marzec M, Wasik MA, Lu P et al. Peroxisome proliferator-activated receptor gamma promotes lymphocyte survival through its actions on cellular metabolic activities. J Immunol 2006; 177: 3737-3745.

65 Clark RB. The role of PPARs in inflammation and immunity. J Leukoc Biol 2002; 71: 388-400.

66 Daynes RA, Jones DC. Emerging roles of PPARs in inflammation and immunity. Nat Rev Immunol 2002; 2: 748-759. 
67 Choi JM, Bothwell AL. The nuclear receptor PPARs as important regulators of T-cell functions and autoimmune diseases. Mol Cells 2012; 33: 217-222.

68 Auboeuf D, Rieusset J, Fajas L, Vallier P, Frering V, Riou JP et al. Tissue distribution and quantification of the expression of mRNAs of peroxisome proliferator-activated receptors and liver $X$ receptor-alpha in humans: no alteration in adipose tissue of obese and NIDDM patients. Diabetes 1997; 46: 1319-1327.

69 Chinetti G, Griglio S, Antonucci M, Torra IP, Delerive P, Majd Z et al. Activation of proliferator-activated receptors alpha and gamma induces apoptosis of human monocyte-derived macrophages. J Biol Chem 1998; 273: 25573-25580.

70 Jones DC, Ding X, Daynes RA. Nuclear receptor peroxisome proliferatoractivated receptor alpha (PPARalpha) is expressed in resting murine lymphocytes. The PPARalpha in T and B lymphocytes is both transactivation and transrepression competent. J Biol Chem 2002; 277: 6838-6845.

71 Gocke AR, Hussain RZ, Yang Y, Peng H, Weiner J, Ben LH et al. Transcriptional modulation of the immune response by peroxisome proliferator-activated receptor-\{alpha\} agonists in autoimmune disease. J Immunol 2009; 182: 4479-4487.

72 Lovett-Racke AE, Hussain RZ, Northrop S, Choy J, Rocchini A, Matthes L et al. Peroxisome proliferator-activated receptor alpha agonists as therapy for autoimmune disease. J Immunol 2004; 172: 5790-5798.

73 Zhang MA, Ahn JJ, Zhao FL, Selvanantham T, Mallevaey T, Stock N et al. Antagonizing peroxisome proliferator-activated receptor $\alpha$ activity selectively enhances Th1 immunity in male mice. J Immunol 2015; 195: 5189-5202.

74 Dubrac S, Elentner A, Schoonjans K, Auwerx J, Schmuth M. Lack of IL-2 in PPAR- $\alpha$-deficient mice triggers allergic contact dermatitis by affecting regulatory T cells. Eur J Immunol 2011; 41: 1980-1991.

75 Polak PE, Kalinin S, Dello Russo C, Gavrilyuk V, Sharp A, Peters JM et al. Protective effects of a peroxisome proliferator-activated receptor-beta/delta agonist in experimental autoimmune encephalomyelitis. J Neuroimmunol 2005; 168: 65-75.

76 Dunn SE, Bhat R, Straus DS, Sobel RA, Axtell R, Johnson A et al. Peroxisome proliferator-activated receptor delta limits the expansion of pathogenic Th cells during central nervous system autoimmunity. J Exp Med 2010; 207: 1599-1608.

77 Mukundan L, Odegaard JI, Morel CR, Heredia JE, Mwangi JW Ricardo-Gonzalez RR et al. PPAR-delta senses and orchestrates clearance of apoptotic cells to promote tolerance. Nat Med 2009; 15: 1266-1272.

78 Fajas L, Auboeuf D, Raspé E, Schoonjans K, Lefebvre AM, Saladin R et al. The organization, promoter analysis, and expression of the human PPARgamma gene. J Biol Chem 1997; 272: 18779-18789.

79 Ricote M, Li AC, Willson TM, Kelly CJ, Glass CK. The peroxisome proliferator-activated receptor-gamma is a negative regulator of macrophage activation. Nature 1998; 391: 79-82.

80 Jiang C, Ting AT, Seed B. PPAR-gamma agonists inhibit production of monocyte inflammatory cytokines. Nature 1998; 391: 82-86.

81 Clark RB, Bishop-Bailey D, Estrada-Hernandez T, Hla T, Puddington L, Padula SJ. The nuclear receptor PPAR and immunoregulation: PPAR mediates inhibition of helper T cell responses. J Immunol 2000; 164: 1364-1371.

82 Klotz L, Schmidt M, Giese T, Sastre M, Knolle P, Klockgether T et al. Proinflammatory stimulation and pioglitazone treatment regulate peroxisome proliferator-activated receptor gamma levels in peripheral blood mononuclear cells from healthy controls and multiple sclerosis patients. J Immunol 2005; 175: 4948-4955.

83 Tobiasova Z, Zhang L, Yi T, Qin L, Manes TD, Kulkarni S et al. Peroxisome proliferator-activated receptor-gamma agonists prevent in vivo remodeling of human artery induced by alloreactive T cells. Circulation 2011; 124: 196-205.
84 Cipolletta D, Feuerer M, Li A, Kamei N, Lee J, Shoelson SE et al. PPAR-gamma is a major driver of the accumulation and phenotype of adipose tissue Treg cells. Nature 2012; 486: 549-553.

85 Cipolletta D, Cohen P, Spiegelman BM, Benoist C, Mathis D. Appearance and disappearance of the mRNA signature characteristic of Treg cells in visceral adipose tissue: age, diet, and PPAR $\gamma$ effects. Proc Natl Acad Sci USA 2015; 112: 482-487.

86 Hontecillas R, Bassaganya-Riera J. Peroxisome proliferator-activated receptor is required for regulatory $\mathrm{CD} 4+\mathrm{T}$ cell-mediated protection against colitis. J Immunol 2007; 178: 2940-2949.

87 Wohlfert EA, Nichols FC, Nevius E, Clark RB. Peroxisome proliferatoractivated receptor gamma (PPARgamma) and immunoregulation: enhancement of regulatory $T$ cells through PPARgamma-dependent and -independent mechanisms. J Immunol 2007; 178: 4129-4135.

88 Housley WJ, Adams CO, Vang AG, Brocke S, Nichols FC, LaCombe M et al. Peroxisome proliferator-activated receptor gamma is required for CD4+ T cell-mediated Iymphopenia-associated autoimmunity. J Immunol 2011; 187: 4161-4169.

89 Bebo BF Jr, Zelinka-Vincent E, Adamus G, Amundson D, Vandenbark AA Offner $\mathrm{H}$. Gonadal hormones influence the immune response to PLP 139-151 and the clinical course of relapsing experimental autoimmune encephalomyelitis. J Neuroimmunol 1998; 84: 122-130.

90 Park HJ, Kim DH, Choi JY, Kim WJ, Kim JY, Senejani AG et al. PPARgamma negatively regulates $\mathrm{T}$ cell activation to prevent follicular helper T cells and germinal center formation. PLOS ONE 2014; 9: e99127.

91 Park HJ, Park HS, Lee JU, Bothwell AL, Choi JM. Gender-specific differences in PPARgamma regulation of follicular helper $\mathrm{T}$ cell responses with estrogen. Sci Rep 2016; 6: 28495

92 Yang XY, Wang LH, Chen T, Hodge DR, Resau JH, DaSilva L et al. Activation of human $\mathrm{T}$ lymphocytes is inhibited by peroxisome proliferatoractivated receptor gamma (PPARgamma) agonists. PPARgamma co-association with transcription factor NFAT. J Biol Chem 2000; 275: 4541-4544.

93 Park HJ, Park HS, Lee JU, Bothwell AL, Choi JM. Sex-based selectivity of PPAR $\gamma$ regulation in Th1, Th2, and Th17 Differentiation. Int $\mathrm{J} \mathrm{Mol} \mathrm{Sci}$ 2016; 17: 1347

94 Klotz L, Burgdorf S, Dani I, Saijo K, Flossdorf J, Hucke S et al. The nuclear receptor PPAR gamma selectively inhibits Th17 differentiation in a T cell-intrinsic fashion and suppresses CNS autoimmunity. J Exp Med 2009; 206: 2079-2089.

95 Park HJ, Kim DH, Lim SH, Kim WJ, Youn J, Choi YS et al. Insights into the role of follicular helper T cells in autoimmunity. Immune Netw 2014; 14: 21-29.

96 Kanakasabai S, Walline CC, Chakraborty S, Bright JJ. PPAR $\delta$ deficient mice develop elevated Th1/Th17 responses and prolonged experimental autoimmune encephalomyelitis. Brain Res 2011; 1376: 101-112.

97 Maher AC, Fu MH, Isfort RJ, Varbanov AR, Qu XA, Tarnopolsky MA. Sex differences in global mRNA content of human skeletal muscle. PLOS ONE 2009; 4: e6335.

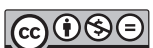

This work is licensed under a Creative Commons Attribution-NonCommercial-NoDerivs 4.0 International License. The images or other third party material in this article are included in the article's Creative Commons license, unless indicated otherwise in the credit line; if the material is not included under the Creative Commons license, users will need to obtain permission from the license holder to reproduce the material. To view a copy of this license, visit http://creativecommons.org/licenses/by-nc-nd/4.0/ 